\title{
Article \\ Synthesis of Indoles by Palladium-Catalyzed Reductive Cyclization of $\beta$-Nitrostyrenes with Phenyl Formate as a CO Surrogate
}

\author{
Francesco Ferretti $^{1}$ (D), Manar Ahmed Fouad ${ }^{1,2}$ (D) and Fabio Ragaini ${ }^{1, *(D)}$ \\ 1 Dipartimento di Chimica, Università degli Studi di Milano, Via C. Golgi 19, 20133 Milano, Italy; \\ francesco.ferretti@unimi.it (F.F.); manar.abdellatif@unimi.it (M.A.F.) \\ 2 Chemistry Department, Faculty of Science, Alexandria University, P.O. Box 426, Alexandria 21321, Egypt \\ * Correspondence: fabio.ragaini@unimi.it
}

Citation: Ferretti, F.; Fouad, M.A.; Ragaini, F. Synthesis of Indoles by Palladium-Catalyzed Reductive Cyclization of $\beta$-Nitrostyrenes with Phenyl Formate as a CO Surrogate. Catalysts 2022, 12, 106. https:// doi.org/10.3390/catal12010106

Academic Editor: Montserrat Diéguez

Received: 30 December 2021

Accepted: 14 January 2022

Published: 17 January 2022

Publisher's Note: MDPI stays neutral with regard to jurisdictional claims in published maps and institutional affiliations.

Copyright: (C) 2022 by the authors. Licensee MDPI, Basel, Switzerland. This article is an open access article distributed under the terms and conditions of the Creative Commons Attribution (CC BY) license (https:// creativecommons.org/licenses/by/ $4.0 /)$.

\begin{abstract}
The reductive cyclization of suitably substituted organic nitro compounds by carbon monoxide is a very appealing technique for the synthesis of heterocycles because of its atom efficiency and easiness of separation of the only stoichiometric byproduct $\mathrm{CO}_{2}$, but the need for pressurized $\mathrm{CO}$ has hampered its diffusion. We have recently reported on the synthesis of indoles by reductive cyclization of $o$-nitrostyrenes using phenyl formate as a CO surrogate, using a palladium/1,10phenanthroline complex as catalyst. However, depending on the desired substituents on the structure, the use of $\beta$-nitrostyrenes as alternative reagents may be advantageous. We report here the results of our study on the possibility to use phenyl formate as a CO surrogate in the synthesis of indoles by reductive cyclization of $\beta$-nitrostyrenes, using $\mathrm{PdCl}_{2}\left(\mathrm{CH}_{3} \mathrm{CN}\right)_{2}+$ phenanthroline as the catalyst. It turned out that good results can be obtained when the starting nitrostyrene bears an aryl substituent in the alpha position. However, when no such substituent is present, only fair yield of indole can be obtained because the base required to decompose the formate also catalyzes an oligo-polymerization of the starting styrene. The reaction can be performed in a single glass pressure tube, a cheap and easily available piece of equipment.
\end{abstract}

Keywords: indoles; nitrostyrenes; cyclization; reduction; carbon monoxide; CO surrogates: palladium; homogeneous catalysis; nitrogen ligands

\section{Introduction}

Indoles represents one of the most important classes of nitrogen heterocycles and many methods have been published for their synthesis [1-5]. Yet, many of the reported procedures employ large amounts of expensive or toxic reagents, whose excess or byproducts may be difficult to remove at the end of the reaction. Among the classes of reactions that can be employed to produce nitrogen heterocycles, reductive cyclization of organic nitro compounds by carbon monoxide is one of the most appealing from this point of view, because only $\mathrm{CO}_{2}$ is formed as a stoichiometric byproduct and the excess of reducing agent is easily removed with the produced $\mathrm{CO}_{2}$ simply upon venting the autoclave [6-12]. Despite these apparent advantages, the use of carbon monoxide as a reducing agent has not spread outside the limited number of groups that have developed these reactions, the reason likely being connected with the difficulty in handling pressurized $\mathrm{CO}$ and with the required safety measurements. The latter problem is also common to other reactions employing pressurized $\mathrm{CO}$ and, in order to circumvent it, the field of so-called $\mathrm{CO}$ surrogates has been intensely developed in the last decade. The latter are solid or liquid molecules able to liberate $\mathrm{CO}$ during the reaction under either a thermal stimulus or the action of a second reagent, typically a base. The use of $\mathrm{CO}$ surrogates has already been reviewed several times [13-17]. 
In the field of reductive cyclization of nitro compounds, we first introduced the use of formate esters for the reductive cyclization of $o$-nitrostyrenes to indoles a few years ago $[18,19]$. Both alkyl- and aryl-formates could be used as CO surrogates, but the latter allowed to obtain higher selectivities and to work under milder conditions. We later extended the use of aryl formates as CO surrogates even to the synthesis of 3,6-dihydro$2 \mathrm{H}$-[1,2]-oxazines from nitroarenes and conjugated dienes [20] and the application to the reductive cyclization of $o$-nitrobiaryls to carbazoles has also been developed [21]. Notably, reaction yields higher than those obtainable by the use of gaseous $\mathrm{CO}$ were achieved in many cases. A related triformate, benzene-1,3.5-triyl triformate, has also been employed by $\mathrm{Wu}$ and coworkers for two reactions in this field: the carbonylation of $o$-nitroanilines to give benzimidazolones [22] and the inter-molecular carbonylation of $o$-nitrobenzyl halides with amines to give 3,4-dihydroquinazolin-2(1H)-ones [23].

Most of the reported reactions for the synthesis of $N$-heterocycles starting from organic nitro compounds and $\mathrm{CO}$ as the reductant employ suitably substituted $o$-nitroarenes as substrates [24-31], although examples of inter-molecular reactions of nitroarenes have also been reported [32-34]. Much less attention has been paid to the use of nitroalkenes as substrates. Dong was the first to report the use of $\alpha$-aryl- $\beta$-nitrostyrenes as substrates for the synthesis of indoles by reductive cyclization using $\mathrm{CO}$ as the reductant [35]. We later extended the range of suitable substrates for the same reaction [36] and also applied as substrates $\beta$-nitrothiophenes, to give thienopyrroles [37], and nitrodienes, to give pyrroles [38]. The use of formates as $\mathrm{CO}$ surrogates in combination with nitroalkenes has not been reported yet, with the exception of a single experiment under unoptimized conditions described in our first communication on the subject [19]. However, it should be mentioned that $\mathrm{Mo}(\mathrm{CO})_{6}$ has been previously employed to this aim [39] and that a single example of a cyclization of this kind employing $\mathrm{CO}_{2}+\left(\mathrm{Ph}_{2} \mathrm{MeSi}\right)_{2}$ has also been reported [40]. In this paper, we describe our studies on the reductive cyclization of $\beta$-nitrostyrenes by phenyl formate as a CO surrogate (Scheme 1).

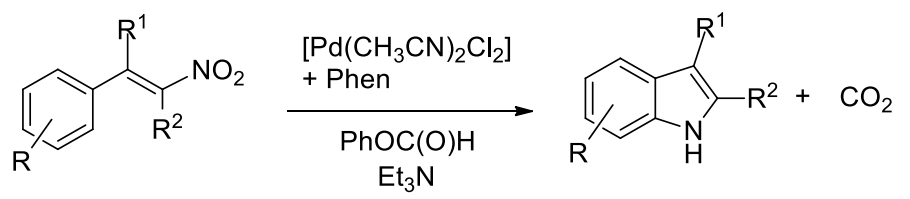

Scheme 1. Synthesis of indoles from $\beta$-nitrostyrenes with $\mathrm{PhOC}(\mathrm{O}) \mathrm{H}$ as a $\mathrm{CO}$ surrogate.

The catalyst employed is an in situ formed complex of palladium with 1,10-phenanthroline (Phen) as ligand. This kind of complexes have proved to be the most active and robust catalysts for reactions involving the reduction of organic nitro compounds not only in the field of cyclization reactions [24,33,41-44], but also in the field of the synthesis of base chemicals such as carbamates and ureas [45-52], where very high turnover numbers are required to make the catalyst economically appealing.

\section{Results and Discussion \\ Optimization of the Reaction Conditions}

The only previously reported data on the use of formate esters as $\mathrm{CO}$ surrogates for the reductive cyclization of a nitroalkene refers to a single preliminary test on the cyclization of $\beta$-methyl- $\beta$-nitrostyrene $\left(\mathrm{R}=\mathrm{R}^{1}=\mathrm{H}, \mathrm{R}^{2}=\mathrm{CH}_{3}\right.$ in Scheme 1 ) employing $\mathrm{PdCl}_{2}\left(\mathrm{CH}_{3} \mathrm{CN}\right)_{2} /$ Phen as catalyst, in $\mathrm{CH}_{3} \mathrm{CN}$ as solvent and with phenyl formate as the $\mathrm{CO}$ surrogate [18]. Triethylamine was employed as the base necessary to catalyze the decomposition of phenyl formate to $\mathrm{CO}$ and phenol. We first reproduced this experiment (Table 1, entry 1), obtaining similar results (39\% selectivity and $80 \%$ conversion vs. $41 \%$ selectivity and $100 \%$ conversion). The small difference is attributable to the different experimental apparatus employed in the two cases (see experimental). Starting from this point, we changed a series of parameters. The main results are here briefly described. 
Table 1. Optimization of the reaction conditions for the reductive cyclization of $\beta$-methyl- $\beta$ nitrostyrene (1a) to 2-methylindole (2a) ${ }^{1}$.

\begin{tabular}{|c|c|c|c|c|c|c|c|}
\hline Entry & Phen (mol\%) & $\mathrm{T}\left({ }^{\circ} \mathrm{C}\right)$ & Base & Base Amount (mmol) & Solvent & Conv. $\%^{2}$ & Select. $\%{ }^{3}$ \\
\hline 1 & 2.5 & 140 & $\mathrm{Et}_{3} \mathrm{~N}$ & 0.29 & $\mathrm{CH}_{3} \mathrm{CN}$ & 80 & 39 \\
\hline 2 & 10 & 140 & $\mathrm{Et}_{3} \mathrm{~N}$ & 2.30 & $\mathrm{CH}_{3} \mathrm{CN}$ & $>99$ & 40 \\
\hline 3 & 10 & 140 & $\mathrm{Et}_{3} \mathrm{~N}$ & 2.30 & THF & 85 & 30 \\
\hline 4 & 10 & 140 & $\mathrm{Et}_{3} \mathrm{~N}$ & 2.30 & DMF & $>99$ & 41 \\
\hline 5 & 10 & 140 & $\mathrm{Et}_{3} \mathrm{~N}$ & 2.30 & $\mathrm{C}_{6} \mathrm{H}_{5} \mathrm{CH}_{3}$ & 52 & 12 \\
\hline 6 & 10 & 140 & $\mathrm{Et}_{3} \mathrm{~N}$ & 2.30 & $\mathrm{CH}_{3} \mathrm{OH}$ & 85 & 9 \\
\hline $7^{4}$ & 10 & 140 & - & - & $\mathrm{CH}_{3} \mathrm{CN}$ & $\sim 0$ & 0 \\
\hline $8^{5}$ & 10 & 140 & $\mathrm{Et}_{3} \mathrm{~N}$ & 2.30 & $\mathrm{CH}_{3} \mathrm{CN}$ & 61 & 0 \\
\hline 9 & 10 & 120 & $\mathrm{Et}_{3} \mathrm{~N}$ & 0.29 & $\mathrm{CH}_{3} \mathrm{CN}$ & 32 & 31 \\
\hline 10 & 10 & 120 & Py & 0.29 & $\mathrm{CH}_{3} \mathrm{CN}$ & $<1$ & $<1$ \\
\hline 11 & 10 & 150 & $\mathrm{Py}$ & 0.29 & $\mathrm{CH}_{3} \mathrm{CN}$ & 17 & 18 \\
\hline 12 & 10 & 120 & $\mathrm{NaOAc}$ & 0.29 & $\mathrm{CH}_{3} \mathrm{CN}$ & 62 & 17 \\
\hline 13 & 10 & 120 & $\mathrm{Na}_{3} \mathrm{PO}_{4}$ & 0.29 & $\mathrm{CH}_{3} \mathrm{CN}$ & 78 & 7 \\
\hline $14^{6}$ & 10 & 140 & $\mathrm{Et}_{3} \mathrm{~N}$ & 2.30 & $\mathrm{CH}_{3} \mathrm{CN}$ & $>99$ & 26 \\
\hline $15^{6}$ & 10 & 140 & $\mathrm{Et}_{3} \mathrm{~N}$ & 0.29 & $\mathrm{CH}_{3} \mathrm{CN}$ & 95 & 28 \\
\hline $16^{7}$ & 10 & 140 & $\mathrm{Et}_{3} \mathrm{~N}$ & 2.30 & $\mathrm{CH}_{3} \mathrm{CN}$ & $>99$ & 47 \\
\hline
\end{tabular}

${ }^{1}$ Experimental conditions: $0.54 \mathrm{mmol} 1 \mathrm{a}, 1 \mathrm{~mol} \% \mathrm{PdCl}_{2}\left(\mathrm{CH}_{3} \mathrm{CN}\right)_{2}, 260 \mu \mathrm{L}(2.38 \mathrm{mmol})$ phenyl formate, in $10 \mathrm{~mL}$ of the indicated solvent, for $7 \mathrm{~h}$; other amounts and conditions as in the table. $0.29 \mathrm{mmol} \mathrm{Et}_{3} \mathrm{~N}$ corresponds to $40 \mu \mathrm{L} ;$ Py $=$ pyridine. ${ }^{2}$ Conversion calculated with respect to starting 1a. ${ }^{3}$ Selectivity in 2a calculated with respect to reacted 1a. ${ }^{4}$ No phenyl formate and no base were added. ${ }^{5}$ No phenyl formate was added. ${ }^{6} 5$ mol $\%$ $\mathrm{PdCl}_{2}\left(\mathrm{CH}_{3} \mathrm{CN}\right)_{2} \cdot{ }^{7} 350 \mu \mathrm{L}$ phenyl formate.

A few explorative tests led to the conclusion that a larger amount of phenanthroline and base afforded a more active and stable catalytic system, even though the selectivity in indole was not improved (Table 2, entry 2). The only other tested solvent (entries 2-6) that gave results comparable to acetonitrile was DMF. However, the latter is a more toxic and less easy to separate from the reaction products than $\mathrm{CH}_{3} \mathrm{CN}$ and we decided not to employ it.

In order to understand the reasons for the failure in reaching selectivities comparable with those previously obtained for the same reaction by the use of gaseous $\mathrm{CO}$ [36], we investigated the stability of the starting $\beta$-nitrostyrene under the reaction conditions and in the presence of only some of the reagents. No reaction was observed under typical reaction conditions in the absence of phenyl formate when only the palladium catalyst and phenanthroline were added (entry 7). However, when the base was also added in the absence of any formate, a significant $61 \%$ consumption of $\beta$-nitrostyrene was observed. A very small amount of benzaldehyde, the product of a retro-Henry hydrolysis of the reagent, was observed by GC and ${ }^{1} \mathrm{H}$ NMR. No other decomposition product could be observed by GC analysis, suggesting that they are oligomeric or polymeric species. $\beta$-Nitrostyrenes are known to be prone to polymerization by a base-catalyzed process [53]. Clearly, a competition is occurring between the cyclization and the decomposition reaction, with the base accelerating both.

Bases different from $\mathrm{Et}_{3} \mathrm{~N}$ could promote the reaction to different extent, but they apparently also promoted the alternative decomposition pathways and the selectivities in indole were always lower (entries 9-13). Increasing the catalyst amount to $5 \mathrm{~mol} \%$ did not solve the problem (entries 14, 15).

At this stage, it is instructive to recall that when gaseous $\mathrm{CO}$ was employed as the reductant for the reductive cyclization of $\beta$-substituted- $\beta$-nitrostyrenes, high selectivities were only observed at CO pressures higher than 20 bar (measured at RT) [36]. Retrospectively, these relatively high pressures are likely needed to speed-up the reduction reaction with respect to the polymerization, which is likely insensitive to the CO pressure. Indeed, the only attempt in which the selectivity in indole could be improved was that performed employing a larger amount of formate (entry 16). However, working with such a large amount of formate is unsafe because in the worst-case scenario, complete decomposition 
of the formate and no $\mathrm{CO}$ consumption, the total pressure inside the reaction vessel at the reaction temperature would exceed 10 bar, which is considered as the safety pressure limit of glass pressure tubes. Thus, we decided not to pursue this strategy any more. Although the problem may be solved by performing the reaction in a steel autoclave, this was not the aim of the present work. The key role of a high $\mathrm{CO}$ pressure is also evidenced by the failure to increase the selectivity of the reaction by increasing the catalyst amount at a fixed formate concentration.

Table 2. Optimization of the reaction conditions for the reductive cyclization of $\alpha$-phenyl- $\beta$ nitrostyrene (1b) to 3-phenylindole $(\mathbf{2 b})^{1}$.

\begin{tabular}{|c|c|c|c|c|c|c|c|c|}
\hline Entry & $\operatorname{Pd}(\mathrm{mol} \%)$ & Phen (mol\%) & $\mathrm{T}\left({ }^{\circ} \mathrm{C}\right)$ & $t(h)$ & $\mathrm{Et}_{3} \mathrm{~N}(\mu \mathrm{L})$ & PhOC(O)H ( $(\mu \mathrm{L})$ & Conv. $\%{ }^{2}$ & Select. $\%{ }^{3}$ \\
\hline 1 & 1 & 5 & 110 & 3 & 120 & 260 & $>99$ & 84 \\
\hline 2 & 1 & 5 & 120 & 3 & 120 & 260 & $>99$ & 87 \\
\hline 3 & 1 & 5 & 130 & 3 & 120 & 260 & $>99$ & 90 \\
\hline 4 & 1 & 5 & 140 & 3 & 120 & 260 & $>99$ & 92 \\
\hline 5 & 1 & 5 & 150 & 3 & 120 & 260 & $>99$ & 77 \\
\hline 6 & 1 & 5 & 140 & 3 & 20 & 260 & $>99$ & 84 \\
\hline 7 & 1 & 5 & 140 & 3 & 40 & 260 & $>99$ & 85 \\
\hline 8 & 1 & 5 & 140 & 3 & 60 & 260 & $>99$ & 87 \\
\hline 9 & 1 & 5 & 140 & 3 & 80 & 260 & $>99$ & 88 \\
\hline 10 & 1 & 5 & 140 & 3 & 120 & 200 & 97 & 81 \\
\hline 11 & 1 & 5 & 140 & 3 & 120 & 350 & $>99$ & 91 \\
\hline 12 & 1 & 5 & 140 & 3 & 200 & 350 & $>99$ & 90 \\
\hline 13 & 1 & 2.5 & 140 & 3 & 120 & 260 & 94 & 85 \\
\hline 14 & 1 & 2.5 & 140 & 3 & 80 & 260 & $>99$ & 83 \\
\hline 15 & 1 & 2.5 & 140 & 7 & 40 & 260 & $>99$ & 87 \\
\hline 16 & 1 & 2.5 & 140 & 16 & 40 & 260 & $>99$ & 87 \\
\hline 17 & 1 & 10 & 140 & 3 & 120 & 260 & $>99$ & 90 \\
\hline 18 & 0.5 & 5 & 140 & 3 & 120 & 260 & $>99$ & 78 \\
\hline 19 & 0.5 & 5 & 140 & 6 & 120 & 260 & $>99$ & 79 \\
\hline $20^{4}$ & 2 & 5 & 140 & 3 & 120 & 260 & $>99$ & 90 \\
\hline $21^{4}$ & 2 & 5 & 140 & 1.5 & 120 & 260 & $>99$ & 90 \\
\hline $22^{5}$ & 1 & 5 & 140 & 3 & 120 & 260 & $>99$ & 88 \\
\hline $23^{6}$ & 1 & 5 & 140 & 3 & 120 & 260 & $>99$ & 85 \\
\hline
\end{tabular}

${ }^{1} 0.54 \mathrm{mmol} \mathbf{1 b}$, in $10 \mathrm{~mL} \mathrm{CH} \mathrm{CN}_{3}$ other amounts and conditions as in the table. ${ }^{2}$ Conversion calculated with respect to starting $\mathbf{1 b}$. ${ }^{3}$ Selectivity in $\mathbf{2} \mathbf{b}$ calculated with respect to reacted $\mathbf{1} \mathbf{b}$. ${ }^{4}$ Pd-black precipitation was observed after $1 \mathrm{~h}$ reaction. ${ }^{5} \mathrm{In} \operatorname{DMF}(10 \mathrm{~mL})$ as solvent. ${ }^{6} \mathrm{In} \mathrm{CH}_{3} \mathrm{CN}+\mathrm{DMF}(9+1 \mathrm{~mL})$ as solvent.

Since the reductive cyclization of $\alpha$-aryl- $\beta$-nitrostyrenes is faster than that of $\beta$ substituted- $\beta$-nitrostyrenes $[35,36]$ we then moved to optimizing the reaction conditions for $\alpha$-phenyl- $\beta$-nitrostyrene (1b, R $=R^{2}=H, R^{1}=P h$ in Scheme 1$)$, also taking into consideration the results described above.

The reaction temperature was first optimized (Table 2, entries 1-5, and Figure 1). As expected, based on the reactivity observed under $\mathrm{CO}$ pressure, the reaction can be performed even at $110^{\circ} \mathrm{C}$. However, the selectivity in the formation of the desired indole increases up to $140^{\circ} \mathrm{C}$, after which a drop is observed.

The effect of the amount of base is moderate, but an almost linear increase in the selectivity is observed at $140{ }^{\circ} \mathrm{C}$ on passing from 20 to $120 \mu \mathrm{L}$ of $\mathrm{Et}_{3} \mathrm{~N}$ (Entries 4, 6-9 and Figure 2).

Decreasing the phenyl formate amount (Entry 10 vs. entry 4) led to an incomplete conversion of the reagent and a lower selectivity in indole, which is not surprising. However, contrary to what observed in the case of $\mathbf{1 a}$, even increasing the formate amount (entry 11) did not improve the selectivity. The difference between the two substrates is likely because whereas the reductive carbonylation of 1 a requires pressures in excess of 20 bar to selectively afford $\mathbf{2 a}$, the corresponding reaction of $\mathbf{1 b}$ can be successfully performed at much lower pressures [35]. Thus, a larger excess of formate is not needed. By working at the larger formate amount, the effect of a larger amount of base was also tested (entry 12), but 
no improvement was observed, indicating that $120 \mu \mathrm{L}$ of $\mathrm{Et}_{3} \mathrm{~N}$ is the best base amount to be added.

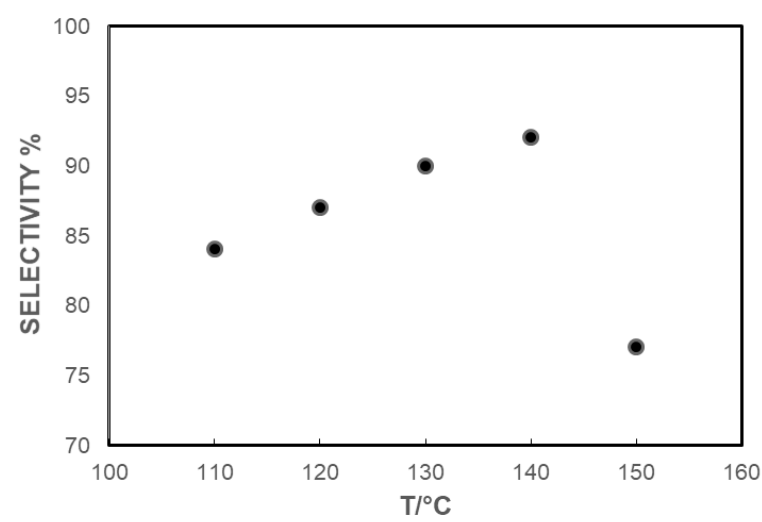

Figure 1. Optimization of the reaction temperature for the reductive cyclization of $\alpha$-phenyl- $\beta$ nitrostyrene (1b) to 2-phenylindole (2b). Data from Table 2.

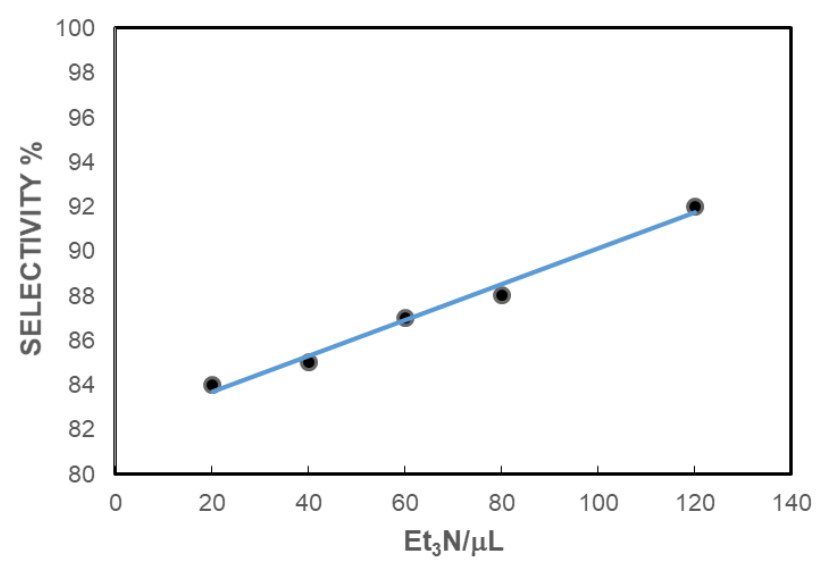

Figure 2. Optimization of the $\mathrm{Et}_{3} \mathrm{~N}$ amount for the reductive cyclization of $\alpha$-phenyl- $\beta$-nitrostyrene (1b) to 2-phenylindole (2b). Data from Table 2.

Halving the amount of phenanthroline (entry 13) led to a less stable catalytic system, but doubling it (entry 17) did not lead to any improvement. At the lowest ligand amount, the effect of a different base concentration and reaction time was also investigated. In particular, a longer reaction time does not alter the selectivity of the reaction (entries 15, 16). This on one side means that $\mathbf{2} \mathbf{b}$ is stable under the reaction conditions; on the other hand the lower selectivity with respect to the ideal conditions is not due to the accumulation of a long-lived intermediate, for example the $N$-hydroxyindole, which only more slowly converts to the final product.

Halving the amount of catalyst decreases the selectivity, an effect that cannot be counterbalanced by an increased reaction time (entries 18, 19). On the other hand, when the amount of catalyst was doubled, the reaction accelerated and was complete in less than one hour (entries 20,21) as evidenced by the formation of palladium black on the walls of the reaction tube, but the selectivity was even decreased with respect to that achievable by working at a $1 \mathrm{~mol} \%$ catalyst amount. Though the decrease in selectivity is not easily explained, the early formation of palladium black is a consequence of the reaction ending in a short time. Indeed, during the reaction the oxidation state of palladium shuttles between zero and two, but zerovalent palladium complexes with nitrogen ligands are not stable under a $\mathrm{CO}$ atmosphere. Thus, if some nitro compound is present that can oxidize back palladium(0) to palladium(II) at a rate faster than decomposition, the reaction can proceed, but if no oxidizing compound is any longer present, then aggregation of the accumulated 
$\operatorname{Pd}(0)$ species results in the bulk metal formation. This behavior is quite standard for palladium-catalyzed carbonylation reactions of nitro organic compounds of any kind.

While this work was in progress, a parallel work in our laboratories evidenced that the use of a $\mathrm{CH}_{3} \mathrm{CN} / \mathrm{DMF}$ (9:1) solvent mixture afforded better results than any of the two solvents separately in the reductive cyclization of $o$-nitrostyrenes to indoles, a reaction with many similarities to that investigated here [18]. We thus tested if the same positive effect could be observed for $\beta$-nitrostyrenes, but both the use of neat DMF and that of the $\mathrm{CH}_{3} \mathrm{CN} / \mathrm{DMF}$ mixture led to a lower indole selectivity (entries 22, 23).

With the optimized conditions in our hands, we investigated the reaction scope of the cyclization (Table 3). The only difference with respect to the optimized conditions was that the reaction time was increased from three to four hours. This was made to maximize chances that substrates less reactive than $\mathbf{1 b}$ could anyway reach a complete consumption in the allowed time.

Table 3. Substrate scope ${ }^{1}$.

Entry


Table 3. Cont.

\begin{tabular}{|c|c|c|c|}
\hline Entry & Substrate & Product & Yield $^{2}$ \\
\hline 7 & & & $67(1: 2.5)$ \\
\hline 8 & & & 70 \\
\hline 9 & 11 & & $71(1.3: 1)$ \\
\hline 10 & נ] & $\mathrm{H}$ & 47 \\
\hline 11 & & & $(34)^{4}$ \\
\hline 12 & & & $-{ }^{5}$ \\
\hline
\end{tabular}

${ }^{1}$ Experimental conditions: $0.54 \mathrm{mmol} \mathrm{1,1} \mathrm{mol} \% \mathrm{PdCl}_{2}\left(\mathrm{CH}_{3} \mathrm{CN}\right)_{2}, 5 \mathrm{~mol} \%$ Phen, $260 \mu \mathrm{L} \mathrm{PhOC}(\mathrm{O}) \mathrm{H}, 120 \mu \mathrm{L}$ $\mathrm{Et}_{3} \mathrm{~N}, 140{ }^{\circ} \mathrm{C}$ for $4 \mathrm{~h}$, in $10 \mathrm{~mL} \mathrm{CH} \mathrm{CN}_{3}{ }^{2}$ Isolated yields. ${ }^{3}$ Experimental conditions: $0.54 \mathrm{mmol} 1,1 \mathrm{~mol} \%$ $\mathrm{PdCl}_{2}\left(\mathrm{CH}_{3} \mathrm{CN}\right)_{2}, 10 \mathrm{~mol} \%$ Phen, $350 \mu \mathrm{L}$ PhOC $(\mathrm{O}) \mathrm{H}, 320 \mu \mathrm{LEt}_{3} \mathrm{~N}, 140{ }^{\circ} \mathrm{C}$ for $7 \mathrm{~h}$, in $10 \mathrm{~mL} \mathrm{CH} \mathrm{CN}^{4}{ }^{4} \mathrm{GC}$ yield in parenthesis. ${ }^{5}$ No product could be isolated.

Before discussing the individual results, it is worth recalling that the initial reduction of the nitro compound has been shown to be an electron transfer from the metal complex to the nitro compound in all of the cases in which this step has been investigated in detail [54-65]. As a consequence, the presence of electron withdrawing groups close to the nitro group accelerates the reaction and that of electron donating groups slows it down. In the present case, it should also be considered that alkenes bearing electron withdrawing groups can coordinate to zerovalent palladium complexes and, specifically, coordination of nitrostyrenes to the $\mathrm{Pd}^{0}\left(2,9-\mathrm{Me}_{2}-4,7-\mathrm{Ph}_{2}-\mathrm{Phen}\right)$ moiety has been experimentally proofed [66]. Coordination to the corresponding moiety with unsubstituted phenanthroline should be even stronger. However, this coordination may have both positive (catalyst stabilization) and negative (catalyst deactivation) effects and these are difficult to analyze without an extensive series of kinetic data. Thus, we will only discuss the former type of contribution. A more comprehensive discussion of the effect of different parameters on reductive carbonylation/cyclization of organic nitro compounds has been reported in a recent review [10] and we address the interested reader to that for more information.

With respect to the substituent on the aryl rings of $\alpha$-aryl- $\beta$-nitrostyrenes, both electron withdrawing groups ( $\mathrm{F}, \mathrm{Cl}$. Table 3, entries 5, 7) and donating $(\mathrm{Me}, \mathrm{MeO}$, entries 3, 8) are well tolerated. The only exception is represented by the very strongly electron donating group dimethylamino (entry 6). This group is often incompatible with this kind of reactions 
and had also failed to give the desired product when $\mathrm{Mo}(\mathrm{CO})_{6}$ had been used as a $\mathrm{CO}$ surrogate [39]. The result is not surprising given what said above concerning the nitro compound activation.

An interesting aspect from the synthetic point of view is the possibility of having a regioselective reaction when two different aryl rings are present in the substrate. It should be recalled that rotation around the central $C=C$ bond is clearly easy under the reaction conditions (see later for the reason). Indeed, $\beta$-alkyl- $\beta$-nitrostyrenes cyclize without problems, both when the reaction is performed under a $\mathrm{CO}$ pressure $[36,37]$ and when in the presence of $\mathrm{Mo}(\mathrm{CO})_{6}$ [39], despite the fact that they are prepared by a Henry condensation that selectively affords the compound with the nitro and aryl groups in the trans position. Despite the lower efficiency of the procedure used in this work for this kind of substrates, the same conclusion clearly apply to the experimental conditions here employed. From a general point of view, the cyclization step should be an aromatic electrophilic substitution reaction and be easier on an electron rich ring. In the previous literature, there is only one example relevant to this point. Cyclization of $(E)-3$-(2-nitropropenyl)thiophene, where a phenyl and a thiophene rings are in competition, afforded a mixture of products with a $55 / 40$ prevalence of that deriving from the functionalization of the electron rich thiophene ring despite the fact that in the reagent the nitro group was selectively oriented towards the phenyl ring [37].

In this work, the possible selectivity of the reaction with respect to the preferentially reacting ring was tested by putting in competition the couples 4-fluorophenyl-4methoxyphenyl, chlorophenyl-phenyl, methyl-phenyl (entries 4, 7, 9). However, only a moderate regioselectivity was observed and a preferential functionalization of the most electron rich ring was observed only in one out of three cases. The obtained regioselectivity does neither match the initial cis-trans ratio in the starting nitroalkenes. This indicates a more complex reaction mechanism, possibly involving an active role by the metal. However, data are at the moment insufficient to draw any general conclusion and a dedicated mechanistic study should be performed to give a final answer to this point.

The reaction is compatible with the presence of both a phenyl ring in the alpha position and methyl group in the beta position of the styrene (entry 10). The better result with respect to that achievable in the absence of the $\alpha$-phenyl substituent (entry 1 ) is further evidence that electronic delocalization effects on both aryl rings of the substrate are the reason for the better results obtainable when an $\alpha$-aryl ring is present. The position of the aryl ring is important and moving it from the alpha to the beta position led to much worse results (entries 2,11).

Given the importance of trifluoromethyl groups in pharmaceutical chemistry, we also synthesized $\alpha$-trifluoromethyl- $\beta$-nitrostyrene ( $1 \mathrm{k})$. However, no indole could be isolated from the corresponding cyclization reaction (entry 12).

Although no specific mechanistic study was made during this study, the obtained results are fully consistent with a scenario analogous to those identified for other related reactions (Scheme 2).

Initially, the active catalyst is generated by coordination of phenanthroline to palladium, followed by reduction of palladium(II) to palladium(0) by the CO liberated by the decomposition of phenyl formate. The so formed complex is able to activate the nitrostyrene by an electron transfer. At this stage, rotation around the weakened $C=C$ double bond can occur. We have previously suggested such possibility based on general orbital considerations [36-38], however, we recently became aware that trans-cis isomerization of $\beta$-nitrostyrenes has indeed been experimentally observed upon generation of the corresponding radical anion [67]. This older report supports the validity of our proposal.

Collapse of the radical couple results in the reduction of the nitro group to nitroso. Electrophilic attack of the nitroso group on the arene then affords a hydroxyindole. It is not certain if this step occurs outside the coordination sphere of the metal or if palladium accelerates it. Hydroxyindoles have been observed or even isolated in related reactions [10]. 
Reduction of the latter by the palladium-carbonyl complex eventually liberates the final indole with regeneration of the active catalyst.

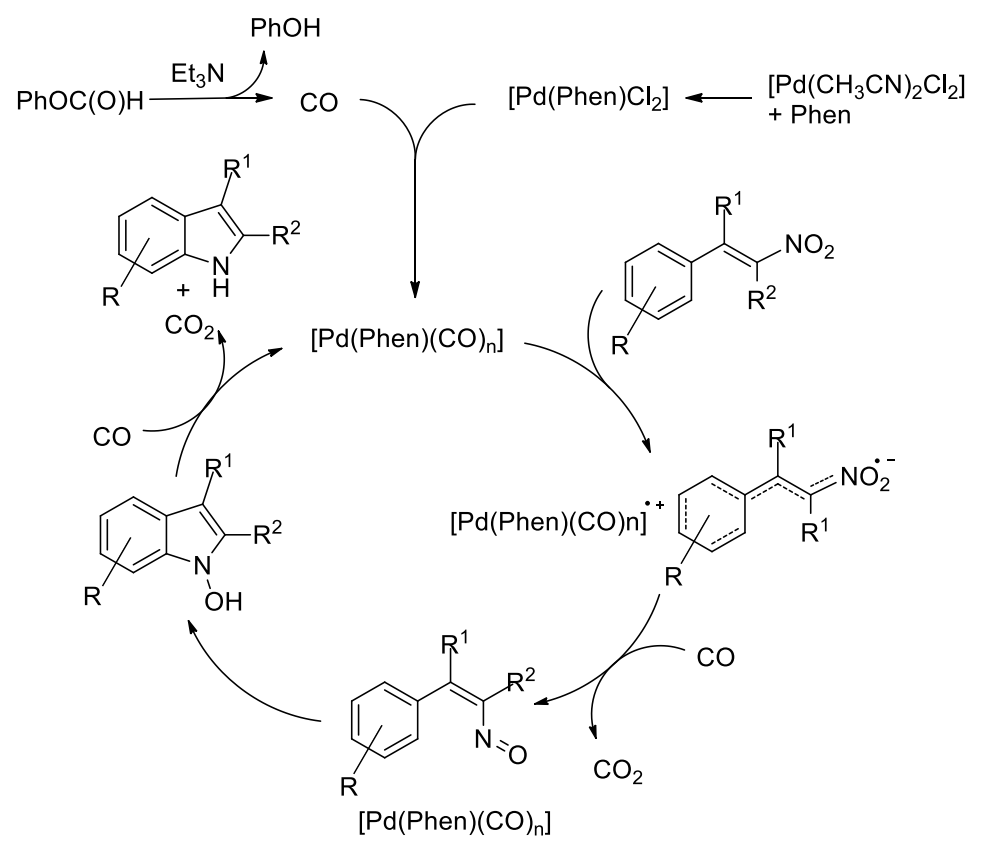

Scheme 2. Proposed reaction mechanism.

\section{Materials and Methods}

\subsection{General Procedures}

All reactions and manipulations were performed under a dinitrogen atmosphere using standard Schlenk apparatus, unless otherwise specified. All glassware and magnetic stirring bars were kept in an oven at $120^{\circ} \mathrm{C}$ for at least two hours and let to cool under vacuum before use. $\mathrm{Et}_{3} \mathrm{~N}$ and $\mathrm{CH}_{3} \mathrm{CN}$ were dried by distillation from $\mathrm{CaH}_{2}$. DMF was dried by distillation over $\mathrm{CaH}_{2}$, under reduced pressure at $60{ }^{\circ} \mathrm{C}$. Dried solvents were stored under a dinitrogen atmosphere. Phenyl formate was prepared following a procedure reported in the literature [68]. Deuterated solvents were purchased from Sigma-Aldrich: $\mathrm{CDCl}_{3}$ was filtered on basic alumina and stored under dinitrogen over $4 \AA$ molecular sieves. 1,10-Phenanthroline (Phen) was purchased as hydrate (TCI Europe NV). It was dissolved in $\mathrm{CH}_{2} \mathrm{Cl}_{2}$, dried over $\mathrm{Na}_{2} \mathrm{SO}_{4}$ followed by filtration under a dinitrogen atmosphere and evaporation of the solvent in vacuo. Phen was weighed in the air but stored under dinitrogen to avoid water uptake. $\mathrm{Pd}\left(\mathrm{CH}_{3} \mathrm{CN}\right) \mathrm{Cl}_{2}$ was prepared starting from commercially available $\mathrm{PdCl}_{2}$ following a procedure reported in the literature [69]. All other reagents were purchased from Merck (Sigma-Aldrich), TCI Europe NV or Fluorochem and used without further purifications. The starting $\beta$-nitrostyrenes were prepared by methods reported in the literature $[39,70,71]$. Details are reported in the Supplementary Materials. ${ }^{1} \mathrm{H}-\mathrm{NMR}$ and ${ }^{13} \mathrm{C}-\mathrm{NMR}$ spectra were recorded on a Bruker Avance DRX 300, Bruker Avance DRX 400 or Avance NEO 400. Chemical shifts are reported in ppm relative to TMS. Gaschromatographic analyses were performed using a Shimadzu 2010Pro gas chromatograph equipped with a Supelco SLB ${ }^{\mathrm{TM}}-5 \mathrm{~ms}$ capillary column $(\mathrm{L} \times \mathrm{I}$.D. $10 \mathrm{~m} \times 0.10 \mathrm{~mm}$, df $0.10 \mu \mathrm{m})$. A standard analysis involves the preparation of a sample solution in $\mathrm{CH}_{2} \mathrm{Cl}_{2}$ (conc. $0.3 \mathrm{mg} / \mathrm{mL}$ calculated with respect to naphthalene used as the internal standard). Elemental analyses were performed on a Perkin Elmer 2400 CHN elemental analyzer.

\subsection{Apparatus}

We have discussed in depth the different kind of pressure tubes that can be employed and the corresponding advantages and disadvantages in a very recent paper [18] and we refer to that paper for a more complete discussion. In the present work, we employed 
$23 \mathrm{~mL}$ Duran heavy walls $(2.5 \mathrm{~mm})$ borosilicate glass tubes with Schott PTB screw caps completed with PTFE protected seals, both commercialized by Fisher Scientific (Figure S1 left, Supplementary Materials), and heated them in a custom-made aluminum block placed on a magnetic stirring and heating plate (Figure S1 right). An oil bath can be alternatively used. CAUTION: Although we never had problems with the pressure tubes over several hundred reactions, the tubes must always be checked for scratches or cracks that may result in a reduced resistance to pressure and the possibility that an explosion occurs should always be considered. Reactions must be performed in a well-ventilated hood and with the use of a protective shield.

\subsection{General Methods for Catalytic Reactions}

To avoid weighing too small amount of substance, stock solutions of Pd catalyst and Phen were separately prepared under dinitrogen in $\mathrm{CH}_{3} \mathrm{CN}$. For a typical catalytic reaction, a pressure tube (see the Apparatus section) equipped with a magnetic stirring bar was charged with the nitrostyrene $(0.54 \mathrm{mmol})$. The tube was placed in a large mouth Schlenk tube and evacuated and filled with dinitrogen three times. The appropriate volume of stock solutions of the catalysts and Phen were added and the mixture stirred for $10 \mathrm{~min}$, to allow the formation of $\mathrm{Pd} / \mathrm{Phen}$ complex. Precipitation of $\mathrm{Pd}(\mathrm{Phen}) \mathrm{Cl}_{2}$ may be observed depending on the catalyst concentration The solvent (total solvent amount was $10 \mathrm{~mL}$ ), $\mathrm{HCOOPh}$ and the base were added in this order and the pressure tube sealed under nitrogen. The tube was then placed in a custom-made aluminum block preheated at the desired temperature and heated while stirring for the required time. Detailed experimental conditions are reported in the captions to the tables.

At the end of the reaction, the pressure tube was lifted from the heating block, let to cool to room temperature and opened (Attention: residual CO pressure is present in the pressure tube, perform the operation slowly under a hood). When quantitative GC analysis of the reaction was needed, naphthalene was then added to the reaction mixture as the internal standard, the reaction stirred until its complete solubilization and then the reaction mixture immediately analyzed. Otherwise, the solvent was evaporated and the residue subjected to column chromatography (silica gel) using hexane/AcOEt as the eluent with the addition of 1 to $2 \%$ of $\mathrm{Et}_{3} \mathrm{~N}$ to partially deactivate acidic sites of silica gel. In our experience, absence of $\mathrm{Et}_{3} \mathrm{~N}$ causes extensive decomposition of the indoles over silica-gel.

\subsection{Characterization Data for Indoles}

2-Methyl-1H-indole (2a). Obtained as a white solid (31 mg, $0.23 \mathrm{mmol}, 43 \%$ yield) after column chromatography (hexane:AcOEt $\left.=90: 10+1 \% \mathrm{Et}_{3} \mathrm{~N}\right) .{ }^{1} \mathrm{H} \mathrm{NMR}(300 \mathrm{MHz}$, $\left.\mathrm{CDCl}_{3}\right): \delta=7.77$ (br s, 1H, NH), $7.51(\mathrm{~d}, J=7.3 \mathrm{~Hz}, 1 \mathrm{H}), 7.26(\mathrm{~d}, J=7.7 \mathrm{~Hz}, 1 \mathrm{H}), 7.15-6.99$ $(\mathrm{m}, 2 \mathrm{H}), 6.22(\mathrm{~s}, 1 \mathrm{H}), 2.43(\mathrm{~s}, 3 \mathrm{H}) \mathrm{ppm} .{ }^{13} \mathrm{C} \mathrm{NMR}\left(75 \mathrm{MHz}^{\mathrm{CDCl}} \mathrm{CD}_{3}\right) \delta 136.1(\mathrm{C}), 135.7(\mathrm{C})$, $129.1(\mathrm{C}), 120.9(\mathrm{CH}), 119.7(\mathrm{CH}), 110.4(\mathrm{CH}), 100.3(\mathrm{CH}), 13.5\left(\mathrm{CH}_{3}\right)$. Elemental Analysis for $\mathrm{C}_{9} \mathrm{H}_{9} \mathrm{~N}$ Calcd.: C, 82.41; H, 6.92; N, 10.48\%. Found: C, 82.12; H, 6.98; N, $10.30 \%$.

3-Phenyl-1H-indole (2b). Obtained as a white solid (93 mg, $0.48 \mathrm{mmol}, 89 \%$ yield) after column chromatography (hexane:AcOEt $\left.=90: 10+1 \% \mathrm{Et}_{3} \mathrm{~N}\right) .{ }^{1} \mathrm{H} \mathrm{NMR}(400 \mathrm{MHz}$, $\left.\mathrm{CDCl}_{3}\right) \delta 8.25(\mathrm{br} \mathrm{s}, 1 \mathrm{H}), 7.98(\mathrm{~d}, J=7.8 \mathrm{~Hz}, 1 \mathrm{H}), 7.71(\mathrm{~d}, J=7.3 \mathrm{~Hz}, 2 \mathrm{H}), 7.52-7.44(\mathrm{~m}, 3 \mathrm{H})$, $7.40(\mathrm{~d}, J=2.1 \mathrm{~Hz}, 1 \mathrm{H}), 7.35-7.26(\mathrm{~m}, 2 \mathrm{H}), 7.23(\mathrm{t}, J=7.4 \mathrm{~Hz}, 1 \mathrm{H}) \mathrm{ppm} .{ }^{13} \mathrm{C} \mathrm{NMR}(75 \mathrm{MHz}$, $\left.\mathrm{CDCl}_{3}\right) \delta 136.8(\mathrm{C}), 135.7(\mathrm{C}), 128.9(\mathrm{CH}), 127.7(\mathrm{CH}), 126.1(\mathrm{CH}), 125.9(\mathrm{C}), 122.6(\mathrm{CH}), 121.9$ $(\mathrm{CH}), 120.5(\mathrm{CH}), 120.0(\mathrm{CH}), 118.5(\mathrm{C}), 111.5(\mathrm{CH}) \mathrm{ppm}$. Elemental Analysis for $\mathrm{C}_{14} \mathrm{H}_{11} \mathrm{~N}$ Calcd.: C, 87.01; H, 5.74; N, 7.25\%. Found: C, 86.90; H, 5.84; N, 7.01\%.

6-methoxy-3-(4-methoxyphenyl)-1H-indole (2c). Obtained as a white solid (92 mg, $0.36 \mathrm{mmol}, 66 \%$ yield) after column chromatography (hexane:AcOEt $=80: 20$ to 60:40 $+1 \%$ $\left.\mathrm{Et}_{3} \mathrm{~N}\right) ; .{ }^{1} \mathrm{H} \mathrm{NMR}\left(300 \mathrm{MHz}, \mathrm{CDCl}_{3}\right) \delta 8.04(\mathrm{br}, 1 \mathrm{H}), 7.76(\mathrm{~d}, J=8.6 \mathrm{~Hz}, 1 \mathrm{H}), 7.57(\mathrm{~d}, J=8.6 \mathrm{~Hz}$, $2 \mathrm{H}), 7.19(\mathrm{~d}, J=2.2 \mathrm{~Hz}, 1 \mathrm{H}), 6.99(\mathrm{~d}, J=8.6 \mathrm{~Hz}, 2 \mathrm{H}), 6.91(\mathrm{~d}, J=1.8 \mathrm{~Hz}, 1 \mathrm{H}), 6.85(\mathrm{dd}, J=8.7$, $2.1 \mathrm{~Hz}, 1 \mathrm{H}), 3.87(\mathrm{~s}, 3 \mathrm{H}), 3.86 \mathrm{ppm}(\mathrm{s}, 3 \mathrm{H}) .{ }^{13} \mathrm{C} \mathrm{NMR}\left(75 \mathrm{MHz}, \mathrm{CDCl}_{3}\right) \delta 158.2(\mathrm{C}), 156.8(\mathrm{C})$, $137.5(\mathrm{C}), 128.6(\mathrm{CH}), 128.3(\mathrm{C}), 120.6(\mathrm{CH}), 120.5(\mathrm{C}), 119.9(\mathrm{CH}), 118.1(\mathrm{C}), 114.4(\mathrm{CH}), 110.2$ 
$(\mathrm{CH}), 94.8(\mathrm{CH}), 55.8\left(\mathrm{OCH}_{3}\right), 55.5$ ppm $\left(\mathrm{OCH}_{3}\right)$. Elemental Analysis for $\mathrm{C}_{16} \mathrm{H}_{15} \mathrm{NO}_{2}$ Calcd.: C, 75.87; H, 5.97; N, 5.53\%. Found: C, 75.90; H, 6.14; N,5.81\%.

3-(4-fluorophenyl)-6-methoxy-1H-indole (2d'). Obtained as a white solid (27 $\mathrm{mg}$, $0.21 \mathrm{mmol}, 21 \%$ yield) after column chromatography (hexane:AcOEt $=85: 15+1 \% \mathrm{Et}_{3} \mathrm{~N}$ ); $21 \%$ yield ${ }^{1} \mathrm{H}$ NMR $\left(400 \mathrm{MHz} \mathrm{CDCl}_{3}\right) \delta 8.08(\mathrm{~s}, 1 \mathrm{H}), 7.73(\mathrm{~d}, J=8.7 \mathrm{~Hz}, 1 \mathrm{H}), 7.65-7.54(\mathrm{~m}$, $2 \mathrm{H}), 7.22(\mathrm{~d}, J=2.4 \mathrm{~Hz}, 1 \mathrm{H}), 7.16-7.09(\mathrm{~m}, 2 \mathrm{H}), 6.92(\mathrm{~d}, J=2.2 \mathrm{~Hz}, 1 \mathrm{H}), 6.86(\mathrm{dd}, J=8.7$, $2.2 \mathrm{~Hz}, 1 \mathrm{H}), 3.87(\mathrm{~s}, 1 \mathrm{H}) \mathrm{ppm} .{ }^{13} \mathrm{C} \mathrm{NMR}\left(75 \mathrm{MHz}, \mathrm{CDCl}_{3}\right) \delta 161.5\left(\mathrm{~d},{ }^{1} J_{\mathrm{C}-\mathrm{F}}=244.4 \mathrm{~Hz}, \mathrm{CF}\right)$, $156.8\left(\mathrm{COCH}_{3}\right), 137.6(\mathrm{C}), 131.8\left(\mathrm{~d},{ }^{4} J_{C-F}=3.1 \mathrm{~Hz}, \mathrm{C}\right), 128.8\left(\mathrm{~d},{ }^{3} J_{C-F}=7.7 \mathrm{~Hz}, \mathrm{CH}\right), 120.5$ $(\mathrm{CH}), 120.3(\mathrm{CH}), 120.2(\mathrm{C}), 117.4(\mathrm{C}), 115.7\left(\mathrm{~d},{ }^{2} J_{C-F}=21.3 \mathrm{~Hz}, \mathrm{CH}\right), 110.5(\mathrm{CH}), 94.9(\mathrm{CH})$, $55.8\left(\mathrm{OCH}_{3}\right)$ ppm. ${ }^{19} \mathrm{~F} \mathrm{NMR}\left(282 \mathrm{MHz}, \mathrm{CDCl}_{3}\right) \delta-117.37$ ppm. Elemental Analysis for $\mathrm{C}_{15} \mathrm{H}_{12}$ FNO Calcd.: C, 74.67; H, 5.01; N, 5.81\%. Found: C, 74.57; H, 5.21; N, 5.61\%.

6-fluoro-3-(4-methoxyphenyl)-1H-indole (2d"). Obtained as a white solid (50 mg, $0.21 \mathrm{mmol}, 38 \%$ yield) after column chromatography (hexane:AcOEt $=85: 15+1 \% \mathrm{Et}_{3} \mathrm{~N}$ ). ${ }^{1} \mathrm{H}$ NMR $\left(300 \mathrm{MHz}, \mathrm{CDCl}_{3}\right) \delta 8.15(\mathrm{~s}, 1 \mathrm{H}), 7.78(\mathrm{dd}, J=8.8,5.4 \mathrm{~Hz}, 1 \mathrm{H}), 7.54(\mathrm{~d}, J=8.7 \mathrm{~Hz}$, 2H), $7.23(\mathrm{~d}, J=2.4 \mathrm{~Hz}, 1 \mathrm{H}), 7.06(\mathrm{dd}, J=9.5,2.3 \mathrm{~Hz}, 1 \mathrm{H}), 7.00(\mathrm{~d}, J=8.7 \mathrm{~Hz}, 2 \mathrm{H}), 6.94$ (ddd, $J=9.4,8.9,2.3 \mathrm{~Hz}, 1 \mathrm{H}), 3.85$ (s, 3H) ppm. ${ }^{13} \mathrm{C} \mathrm{NMR}\left(75 \mathrm{MHz}, \mathrm{CDCl}_{3}\right) \delta 160.5(\mathrm{~d}$, $\left.{ }^{1} J_{C-F}=238.2 \mathrm{~Hz}, \mathrm{CF}\right), 158.7\left(\mathrm{COCH}_{3}\right), 136.9\left(\mathrm{~d},{ }^{3} J_{C-F}=12.4 \mathrm{~Hz}, \mathrm{C}\right), 129.0(\mathrm{CH}), 128.1(\mathrm{C})$, $123.0(\mathrm{C}) 121.7\left(\mathrm{~d},{ }^{3} J_{\mathrm{C}-\mathrm{F}}=3.3 \mathrm{~Hz}, \mathrm{CH}\right), 121.0\left(\mathrm{~d},{ }^{3} J_{C-F}=10.1 \mathrm{~Hz}, \mathrm{CH}\right), 118.5(\mathrm{C}), 114.7(\mathrm{CH})$, $109.3\left(\mathrm{~d},{ }^{2} J_{C-F}=24.4 \mathrm{~Hz}, \mathrm{CH}\right), 98.0\left(\mathrm{~d},{ }^{2} J_{\mathrm{C}-\mathrm{F}}=26.0 \mathrm{~Hz}, \mathrm{CH}\right), 55.8\left(\mathrm{OCH}_{3}\right) \mathrm{ppm} .{ }^{19} \mathrm{~F}$ NMR (282 MHz, $\left.\mathrm{CD}_{2} \mathrm{Cl}_{2}\right) \delta$-121.17 ppm. Elemental Analysis for $\mathrm{C}_{15} \mathrm{H}_{12} \mathrm{FNO}$ Calcd.: C, 74.67; $\mathrm{H}$, $5.01 ; \mathrm{N}, 5.81 \%$. Found: C, 74.78; H, 5.31; N, 5.49\%.

6-fluoro-3-(4-fluorophenyl)-1H-indole (2e). Obtained as an off-white solid (61 mg, $0.27 \mathrm{mmol}, 49 \%$ yield) after column chromatography (hexane:AcOEt $=90: 10+1 \% \mathrm{Et}_{3} \mathrm{~N}$ ). ${ }^{1} \mathrm{H} \mathrm{NMR}\left(300 \mathrm{MHz} \mathrm{CDCl}_{3}\right) \delta 8.21(\mathrm{~s}, 1 \mathrm{H}), 7.77(\mathrm{dd}, J=8.7,5.3 \mathrm{~Hz}, 1 \mathrm{H}), 7.63-7.54(\mathrm{~m}, 3 \mathrm{H})$, $7.28(\mathrm{~d}, J=2.3 \mathrm{~Hz}, 1 \mathrm{H}), 7.20-7.08(\mathrm{~m}, 4 \mathrm{H}), 6.97(\mathrm{td}, J=9.3,2.2 \mathrm{~Hz}, 1 \mathrm{H}) \mathrm{ppm} .{ }^{13} \mathrm{C} \mathrm{NMR}$ $\left(75 \mathrm{MHz}, \mathrm{CDCl}_{3}\right) \delta 161.7\left(\mathrm{~d},{ }^{1} J_{C-F}=244.9 \mathrm{~Hz}, \mathrm{C}\right), 160.2\left(\mathrm{~d},{ }^{1} J_{C-F}=238.6 \mathrm{~Hz}, \mathrm{C}\right), 136.7(\mathrm{~d}$, $\left.{ }^{3} J_{C-F}=12.4 \mathrm{~Hz}, C\right), 131.3\left(\mathrm{~d},{ }^{4} J_{C-F}=3.3 \mathrm{~Hz}, C\right), 129.0\left(\mathrm{~d},{ }^{3} J_{C-F}=7.8 \mathrm{~Hz}, C H\right), 122.5(C), 121.9$ $\left(\mathrm{d},{ }^{3} J_{C-F}=3.3 \mathrm{~Hz}, C H\right), 120.5\left(\mathrm{~d},{ }^{3} J_{C-F}=10.1 \mathrm{~Hz}, C H\right), 117.7(\mathrm{C}), 115.8\left(\mathrm{~d},{ }^{2} J_{C-F}=21.4 \mathrm{~Hz}\right.$, $\mathrm{CH}), 109.28\left(\mathrm{~d},{ }^{2} J_{C-F}=24.4 \mathrm{~Hz}, \mathrm{CH}\right), 97.82\left(\mathrm{~d},{ }^{2} J_{C-F}=26.0 \mathrm{~Hz}, \mathrm{CH}\right) \mathrm{ppm} .{ }^{19} \mathrm{~F}$ NMR $(282 \mathrm{MHz}$, $\left.\mathrm{CDCl}_{3}\right) \delta$-116.84, -120.78 ppm. Elemental Analysis for $\mathrm{C}_{14} \mathrm{H}_{9} \mathrm{~F}_{2} \mathrm{~N}$ Calcd.: C, 73.36; H, 3.96; N, 6.11\%. Found: C, 72.95; H, 4.27; N, 5.84\%.

3-(4-chlorophenyl)-1H-indole ( $\left.2 \mathrm{~g}^{\prime}\right)$ and 6-chloro-3-phenyl-1H-indole $\left(\mathbf{2} \mathbf{g}^{\prime \prime}\right)$. Obtained as an off-white solid ( $82 \mathrm{mg}, 0.36 \mathrm{mmol}, 67 \%$ yield) after column chromatography (hexane:AcOEt $\left.=90: 10+1 \% \mathrm{Et}_{3} \mathrm{~N}\right) .{ }^{1} \mathrm{H} \mathrm{NMR}\left(400 \mathrm{MHz}, \mathrm{CDCl}_{3}\right) \delta 8.25\left(\mathrm{~s}, 1 \mathrm{H}, \mathrm{NH}, \mathbf{2} \mathbf{g}^{\prime}\right.$ isomer), $8.20\left(\mathrm{~s}, 1 \mathrm{H}, \mathrm{NH}, \mathbf{2} \mathrm{g}^{\prime \prime}\right.$ isomer), $7.90\left(\mathrm{~d}, J=7.9 \mathrm{~Hz}, 1 \mathrm{H}, \mathbf{2 \mathrm { g } ^ { \prime }}\right.$ isomer $), 7.84(\mathrm{~d}, J=8.5 \mathrm{~Hz}, 1 \mathrm{H}$, $2 \mathbf{g}^{\prime \prime}$ isomer), $7.64\left(\mathrm{~d}, J=7.8 \mathrm{~Hz}, 2 \mathrm{H}, \mathbf{2} \mathrm{g}^{\prime \prime}\right.$ isomer $), 7.60\left(\mathrm{~d}, J=8.4 \mathrm{~Hz}, 2 \mathrm{H}, \mathbf{2} \mathrm{g}^{\prime}\right.$ isomer $), 7.46(\mathrm{t}$, $J=7.7 \mathrm{~Hz}, 2 \mathrm{H}, \mathbf{2} \mathbf{g}^{\prime \prime}$ isomer), $7.45-7.39\left(\mathrm{~m}, 3 \mathrm{H}, \mathbf{2} \mathbf{g}^{\prime}\right.$ isomer and $1 \mathrm{H}, \mathbf{2} \mathbf{g}^{\prime \prime}$ isomer), $7.35-7.20(\mathrm{~m}$, $3 \mathrm{H}, \mathbf{2} \mathbf{g}^{\prime}$ isomer and $2 \mathrm{H}, \mathbf{2} \mathbf{g}^{\prime \prime}$ isomer), $7.17\left(\mathrm{dd}, J=8.6,1.8 \mathrm{~Hz}, 1 \mathrm{H}, \mathbf{2} \mathbf{g}\right.$ " isomer) ppm. ${ }^{13} \mathrm{C} \mathrm{NMR}$ $\left(75 \mathrm{MHz}, \mathrm{CDCl}_{3}\right) \delta 137.1\left(\mathrm{C}, \mathbf{2} \mathbf{g}^{\prime \prime}\right), 135.1\left(\mathrm{C}, \mathbf{2} \mathbf{g}^{\prime \prime}\right), 129.03\left(\mathrm{CH}, \mathbf{2} \mathbf{g}^{\prime}\right), 128.99\left(\mathrm{CH}, \mathbf{2} \mathbf{g}^{\prime \prime}\right), 128.7$ $\left(\mathrm{CH}, \mathbf{2 g}^{\prime}\right), 128.4\left(\mathrm{C}, \mathbf{2} \mathbf{g}^{\prime \prime}\right), 127.6\left(\mathrm{CH}, \mathbf{2} \mathbf{g}^{\prime \prime}\right), 126.4\left(\mathrm{CH}, \mathbf{2} \mathbf{g}^{\prime \prime}\right), 124.6\left(\mathrm{C}, \mathbf{2} \mathbf{g}^{\prime \prime}\right), 122.7\left(\mathrm{CH}, \mathbf{2} \mathbf{g}^{\prime}\right), 122.4$ $\left(\mathrm{CH}, \mathbf{2} \mathbf{g}^{\prime \prime}\right), 122.0\left(\mathrm{CH}, \mathbf{2} \mathbf{g}^{\prime}\right), 121.2\left(\mathrm{CH}, \mathbf{2} \mathbf{g}^{\prime \prime}\right), 120.7\left(\mathrm{CH}, \mathbf{2} \mathbf{g}^{\prime \prime}\right), 120.6\left(\mathrm{CH}, \mathbf{2} \mathbf{g}^{\prime}\right), 119.7\left(\mathrm{CH}, \mathbf{2} \mathbf{g}^{\prime}\right)$, 118. (C, $\left.\mathbf{2} \mathbf{g}^{\prime \prime}\right), 117.3\left(\mathrm{C}, \mathbf{2} \mathbf{g}^{\prime}\right), 111.6\left(\mathrm{CH}, \mathbf{2} \mathbf{g}^{\prime}\right), 111.4\left(\mathrm{CH}, \mathbf{2} \mathbf{g}^{\prime \prime}\right)$ ppm. Elemental Analysis for $\mathrm{C}_{14} \mathrm{H}_{10} \mathrm{ClN}$ Calcd.: C, 73.85; H, 4.43; N, 6.15\%. Found: C, 74.15; H, 4.53; N, 5.84\%.

6-methyl-3-(4-methylphenyl)-1H-indole (2h). Obtained as a white solid (83 $\mathrm{mg}$, $0.38 \mathrm{mmol}, 70 \%$ yield) after column chromatography (hexane:AcOEt $=90: 10+1 \% \mathrm{Et}_{3} \mathrm{~N}$ ). ${ }^{1} \mathrm{H} \mathrm{NMR}\left(400 \mathrm{MHz}, \mathrm{CDCl}_{3}\right) \delta 8.06(\mathrm{br}, 1 \mathrm{H}), 7.81(\mathrm{~d}, J=8.2 \mathrm{~Hz}, 1 \mathrm{H}), 7.57(\mathrm{~d}, J=8.0 \mathrm{~Hz}, 2 \mathrm{H})$, 7.27-7.25 (m, 3H, overlapped with $\left.\mathrm{CDCl}_{3}\right), 7.21(\mathrm{~s}, 1 \mathrm{H}), 7.03(\mathrm{~d}, J=8.2 \mathrm{~Hz}, 1 \mathrm{H}), 2.49(\mathrm{~s}, 3 \mathrm{H})$, 2.41 (s, 3H) ppm. ${ }^{13} \mathrm{C}$ NMR (100 MHz, $\left.\mathrm{CDCl}_{3}\right) \delta 137.3(\mathrm{C}), 135.6(\mathrm{C}), 132.9(\mathrm{C}), 132.3(\mathrm{C})$, $129.6(\mathrm{CH}), 127.4(\mathrm{CH}), 123.9(\mathrm{C}), 122.1(\mathrm{CH}), 120.9(\mathrm{CH}), 119.7(\mathrm{CH}), 118.3(\mathrm{C}), 111.4(\mathrm{CH})$, $21.8\left(\mathrm{CH}_{3}\right), 21.3\left(\mathrm{CH}_{3}\right)$ ppm. Elemental Analysis for $\mathrm{C}_{16} \mathrm{H}_{15} \mathrm{~N} \mathrm{Calcd}$.: $\mathrm{C}, 86.84 ; \mathrm{H}, 6.83$; $\mathrm{N}$, 6.33\%. Found: C, 87.10; H, 6.98; N, 6.02\%.

6-methyl-3-phenyl-1H-indole ( $\left.2 \mathbf{i}^{\prime}\right)$ and 3-(4-methylphenyl)-1H-indole ( $\left.2 \mathbf{i}^{\prime \prime}\right)$. Obtained as a pale-yellow solid (78 $\mathrm{mg}, 0.38 \mathrm{mmol}, 71 \%$ yield, mixture of the two isomers $2 \mathbf{i}^{\prime}$ and $\mathbf{2 i}^{\prime \prime}$, ratio $\mathbf{2} \mathbf{i}^{\prime}: \mathbf{2} \mathbf{i}^{\prime \prime}=1.3: 1$ ) after column chromatography (hexane:AcOEt $\left.=90: 10+1 \% \mathrm{Et}_{3} \mathrm{~N}\right)$. 
${ }^{1} \mathrm{H}$ NMR (400 MHz, $\left.\mathrm{CDCl}_{3}\right) \delta 8.18\left(\mathrm{br}, 1 \mathrm{H}, \mathbf{2 i} \mathbf{i}^{\prime \prime}\right.$ isomer), 8.08 (br, 1H, 2i' isomer), $7.95(\mathrm{~d}$, $J=7.9 \mathrm{~Hz}, 1 \mathrm{H}, \mathbf{2 i}^{\prime \prime}$ isomer), $7.85\left(\mathrm{~d}, J=8.2 \mathrm{~Hz}, 1 \mathrm{H}, \mathbf{2 i}^{\prime}\right.$ isomer $), 7.69\left(\mathrm{~d}, J=7.2 \mathrm{~Hz}, 2 \mathrm{H}, \mathbf{2}^{\prime}\right.$ isomer), $7.59\left(\mathrm{~d}, J=8.0 \mathrm{~Hz}, 2 \mathrm{H}, \mathbf{2} \mathbf{i}^{\prime \prime}\right.$ isomer), 7.50-7.40 (m, 2H, 2i' isomer and $1 \mathrm{H}, \mathbf{2} \mathbf{i}^{\prime \prime}$ isomer), 7.36-7.17 (m, 3H, 2i' isomer and 5H, 2i' $\mathbf{i}^{\prime \prime}$ isomer, overlapped with $\left.\mathrm{CDCl}_{3}\right), 7.05(\mathrm{~d}, \mathrm{~J}=8.2 \mathrm{~Hz}$, $1 \mathrm{H}, \mathbf{2} \mathbf{i}^{\prime}$ isomer), 2.51 (s, 3H, $2 \mathbf{i}^{\prime}$ isomer), 2.43 (s, 3H, $2 \mathbf{i}^{\prime \prime}$ isomer) ppm. ${ }^{13} \mathrm{C} \mathrm{NMR}(100 \mathrm{MHz}$, $\left.\mathrm{CDCl}_{3}\right) \delta 137.2\left(C, \mathbf{2} \mathbf{i}^{\prime}\right.$ isomer), $136.8\left(C, \mathbf{2} \mathbf{i}^{\prime \prime}\right.$ isomer), $135.9(C), 135.7(C), 132.7\left(C, \mathbf{2} \mathbf{i}^{\prime}\right.$ isomer), $132.4\left(\mathrm{C}, \mathbf{2} \mathbf{i}^{\prime}\right.$ isomer), $129.6\left(\mathrm{CH}, \mathbf{2} \mathbf{i}^{\prime \prime}\right.$ isomer $), 128.9\left(\mathrm{CH}, \mathbf{2} \mathbf{i}^{\prime}\right.$ isomer $), 127.6\left(\mathrm{CH}, \mathbf{2} \mathbf{i}^{\prime \prime}\right.$ isomer $)$, $127.5\left(\mathrm{CH}, \mathbf{2} \mathbf{i}^{\prime}\right.$ isomer), $126.0\left(\mathrm{CH}\right.$, both isomers), 123.7 (C, $\mathbf{2} \mathbf{i}^{\prime}$ isomer $), 122.5\left(\mathrm{CH}, \mathbf{2} \mathbf{i}^{\prime \prime}\right.$ isomer), 122.2 (CH, 2i' isomer), $121.6\left(\mathrm{CH}, \mathbf{2} \mathbf{i}^{\prime \prime}\right.$ isomer), $121.2\left(\mathrm{CH}, \mathbf{2} \mathbf{i}^{\prime}\right.$ isomer), $120.3\left(\mathrm{CH}, \mathbf{2} \mathbf{i}^{\prime \prime}\right.$ isomer), 120.0 (CH, 2i' isomer), $119.6\left(\mathrm{CH}, \mathbf{2} \mathbf{i}^{\prime}\right.$ isomer), 118.5 (C, 2i'” isomer), 118.3 (C, 2i' isomer), 111.5 (CH, 2i' isomer), $111.4\left(\mathrm{CH}, \mathbf{2} \mathbf{i}^{\prime}\right.$ isomer $), 21.8\left(\mathrm{CH}_{3}, \mathbf{2} \mathbf{i}^{\prime \prime}\right.$ isomer $), 21.3\left(\mathrm{CH}_{3}, \mathbf{2} \mathbf{i}^{\prime \prime}\right.$ isomer ppm. Elemental Analysis for $\mathrm{C}_{15} \mathrm{H}_{13} \mathrm{~N}$ Calcd.: $\mathrm{C}, 86.92 ; \mathrm{H}, 6.32 ; \mathrm{N}, 6.76 \%$. Found: $\mathrm{C}, 87.22$; $\mathrm{H}, 6.57 ; \mathrm{N}, 6.44 \%$.

2-methyl-3-phenyl-1H-indole (2j). Obtained as a yellow gum (53 mg, $0.26 \mathrm{mmol}, 47 \%$ yield) after column chromatography (hexane:AcOEt $\left.=95: 5+1 \% \mathrm{Et}_{3} \mathrm{~N}\right) .{ }^{1} \mathrm{H} \mathrm{NMR}(400 \mathrm{MHz}$, $\left.\mathrm{CDCl}_{3}\right) \delta 7.96(\mathrm{br}, 1 \mathrm{H}), 7.68(\mathrm{~d}, J=7.8 \mathrm{~Hz}, 1 \mathrm{H}), 7.53(\mathrm{dd}, J=8.2,1.3 \mathrm{~Hz}, 2 \mathrm{H}), 7.47(\mathrm{t}, J=7.7 \mathrm{~Hz}$, $2 \mathrm{H}), 7.37-7.29(\mathrm{~m}, 2 \mathrm{H}), 7.18(\mathrm{td}, J=7.6,1.1 \mathrm{~Hz}, 1 \mathrm{H}), 7.12(\mathrm{td}, J=7.6,1.1 \mathrm{~Hz}, 1 \mathrm{H}), 2.52(\mathrm{~s}, 3 \mathrm{H})$ ppm. ${ }^{13} \mathrm{C}$ NMR $\left(100 \mathrm{MHz}, \mathrm{CDCl}_{3}\right) \delta 135.6(\mathrm{C}), 135.4(\mathrm{C}), 131.5(\mathrm{C}), 129.6(\mathrm{CH}), 128.6(\mathrm{CH})$, $128.0(\mathrm{C}), 125.9(\mathrm{CH}), 121.7(\mathrm{CH}), 120.1(\mathrm{CH}), 118.9(\mathrm{CH}), 114.7(\mathrm{C}), 110.4(\mathrm{CH}), 12.7\left(\mathrm{CH}_{3}\right)$ ppm. Elemental Analysis for $\mathrm{C}_{15} \mathrm{H}_{13} \mathrm{~N}$ Calcd.: $\mathrm{C}, 86.92 ; \mathrm{H}, 6.32 ; \mathrm{N}, 6.76 \%$. Found: $\mathrm{C}, 87.18$; $\mathrm{H}, 6.52 ; \mathrm{N}, 6.55 \%$.

\section{Conclusions}

In this work, we have extended the use of phenyl formate as a CO surrogate to the reductive cyclization of $\beta$-nitrostyrenes. Good results could be reached when a second aryl ring is present in the alpha position of the styrene. Depending on the substrate, results are comparable to or a little worse than those achievable by the use of pressurized gaseous $\mathrm{CO}$. However, the reaction was not satisfactory when no aryl substituent was present in the alpha position of the nitrostyrene, at least when the results previously achieved by the use of pressurized $\mathrm{CO}$ are taken as a reference. That the latter substrates required harsher reaction conditions had already been noted, but this fact had only been imputed to a lower reactivity of starting nitroalkene. In this work, we have found that the lower reactivity is only one aspect of the problem. The other is that bases, necessary for the decomposition of phenyl formate, promote unwanted side reactions, apparently oligo- and polymerization reactions. Thus, a competition exists between the cyclization and the secondary reactions and the only efficient way of favoring the former is to increase the CO pressure. Even if the problem may be in theory solved by increasing the phenyl formate amount, this cannot be safely done in a glass pressure tube. For these substrates, the use of pressurized CO [36] seems to us to still be the best choice, but employing $\mathrm{Mo}(\mathrm{CO})_{6}$ as a $\mathrm{CO}$ surrogate that does not require the presence of a base to be activated [39] appears anyway to allow for better results than those achievable by using phenyl formate.

Supplementary Materials: The following supporting information can be downloaded at https: / / www.mdpi.com/article/10.3390/catal12010106/s1, Experimental details for the synthesis of the starting nitroalkenes. Figure S1: Picture of the pressure tube and heating apparatus employed. Figures S2-S22: copies of NMR spectra.

Author Contributions: Methodology, F.F. and M.A.F.; investigation, F.F. and M.A.F.; writing-original draft preparation, F.R. and F.F.; supervision, F.R. All authors have read and agreed to the published version of the manuscript.

Funding: This research was funded by the Università degli Studi di Milano, PSR 2020-project: "Sustainable catalytic strategies for the synthesis of high added-value fine-chemicals".

Acknowledgments: We thank M. Gialli for experimental assistance. 
Conflicts of Interest: The authors declare no conflict of interest. The funders had no role in the design of the study; in the collection, analyses, or interpretation of data; in the writing of the manuscript, or in the decision to publish the results.

\section{References}

1. Bandini, M.; Eichholzer, A. Catalytic Functionalization of Indoles in a New Dimension. Angew. Chem. Int. Ed. 2009, 48, 9608-9644. [CrossRef]

2. Mathada, B.S.; Yernale, N.G.; Basha, J.N.; Badiger, J. An insight into the advanced synthetic recipes to access ubiquitous indole heterocycles. Tetrahedron Lett. 2021, 85, 153458. [CrossRef]

3. Ayesha; Bilal, M.; Rasool, N.; Khan, S.G.; Rashid, U.; Altaf, H.; Ali, I. Synthesis of Indoles via Intermolecular and Intramolecular Cyclization by Using Palladium-Based Catalysts. Catalysts 2021, 11, 1018. [CrossRef]

4. Bartoli, G.; Dalpozzo, R.; Nardi, M. Applications of Bartoli indole synthesis. Chem. Soc. Rev. 2014, 43, 4728-4750. [CrossRef] [PubMed]

5. Humphrey, G.R.; Kuethe, J.T. Practical Methodologies for the Synthesis of Indoles. Chem. Rev. 2006, 106, 2875-2911. [CrossRef]

6. Cenini, S.; Ragaini, F. Catalytic Reductive Carbonylation of Organic Nitro Compounds; Kluwer Academic Publishers: Dordrecht, The Netherlands, 1996.

7. Soderberg, B.C.G. Synthesis of heterocycles via intramolecular annulation of nitrene intermediates. Curr. Org. Chem. 2000, 4, 727-764. [CrossRef]

8. Ragaini, F.; Cenini, S.; Gallo, E.; Caselli, A.; Fantauzzi, S. Fine chemicals by reductive carbonylation of nitroarenes, catalyzed by transition metal complexes. Curr. Org. Chem. 2006, 10, 1479-1510. [CrossRef]

9. Ferretti, F.; Formenti, D.; Ragaini, F. The reduction of organic nitro compounds by carbon monoxide as an effective strategy for the synthesis of N-heterocyclic compounds: A personal account. Rend. Lincei 2017, 28, 97-115. [CrossRef]

10. Ferretti, F.; Ramadan, D.R.; Ragaini, F. Transition Metal Catalyzed Reductive Cyclization Reactions of Nitroarenes and Nitroalkenes. ChemCatChem 2019, 11, 4450-4488. [CrossRef]

11. Afanasyev, O.I.; Chusov, D. Carbon Monoxide Related Reductions. Ineos Open 2020, 3, 133-139. [CrossRef]

12. Tsygankov, A.A.; Makarova, M.; Chusov, D. Carbon monoxide as a selective reducing agent in organic chemistry. Mendeleev Commun. 2018, 28, 113-122. [CrossRef]

13. Peng, J.B.; Qi, X.X.; Wu, X.F. Recent Achievements in Carbonylation Reactions: A Personal Account. Synlett 2017, $28,175-194$.

14. Wu, L.; Liu, Q.; Jackstell, R.; Beller, M. Carbonylations of Alkenes with CO Surrogates. Angew. Chem. Int. Ed. 2014, 53, 6310-6320. [CrossRef] [PubMed]

15. Konishi, H.; Manabe, K. Formic Acid Derivatives as Practical Carbon Monoxide Surrogates for Metal-Catalyzed Carbonylation Reactions. Synlett 2014, 25, 1971-1986. [CrossRef]

16. Gautam, P.; Bhanage, B.M. Recent advances in the transition metal catalyzed carbonylation of alkynes, arenes and aryl halides using CO surrogates. Catal. Sci. Technol. 2015, 5, 4663-4702. [CrossRef]

17. Friis, S.D.; Lindhardt, A.T.; Skrydstrup, T. The Development and Application of Two-Chamber Reactors and Carbon Monoxide Precursors for Safe Carbonylation Reactions. Acc. Chem. Res. 2016, 49, 594-605. [CrossRef]

18. Fouad, M.A.; Ferretti, F.; Formenti, D.; Milani, F.; Ragaini, F. Synthesis of Indoles by Reductive Cyclization of Nitro Compounds Using Formate Esters as CO Surrogates. Eur. J. Org. Chem. 2021, 2021, 4876-4894. [CrossRef]

19. Formenti, D.; Ferretti, F.; Ragaini, F. Synthesis of N-Heterocycles by Reductive Cyclization of Nitro Compounds using Formate Esters as Carbon Monoxide Surrogates. ChemCatChem 2018, 10, 148-152. [CrossRef]

20. EL-Atawy, M.A.; Formenti, D.; Ferretti, F.; Ragaini, F. Synthesis of 3,6-Dihydro-2H-[1,2]-Oxazines from Nitroarenes and Conjugated Dienes, Catalyzed by Palladium/Phenanthroline Complexes and Employing Phenyl Formate as a CO Surrogate. ChemCatChem 2018, 10, 4707-4717. [CrossRef]

21. Ramadan, D.R.; Ferretti, F.; Ragaini, F. Synthesis of Carbazoles: Use of Formate Esters as CO Surrogates and Pd/Phen Complexes as Catalysts for Reductive Cyclization of 2-Nitrobiphenyls. In Proceedings of the Cutting-Edge Homogeneous Catalysis (CEHC-1), Toulouse, France, 4-6 May 2021; p. 26.

22. Qi, X.; Zhou, R.; Peng, J.-B.; Ying, J.; Wu, X.-F. Selenium-Catalyzed Carbonylative Synthesis of 2-Benzimidazolones from 2-Nitroanilines with TFBen as the CO Source. Eur. J. Org. Chem. 2019, 2019, 5161-5164. [CrossRef]

23. Zhou, R.; Qi, X.; Wu, X.-F. Selenium-Catalyzed Carbonylative Synthesis of 3,4-Dihydroquinazolin-2(1H)-one Derivatives with TFBen as the CO Source. ACS Comb. Sci. 2019, 21, 573-577. [CrossRef] [PubMed]

24. Tollari, S.; Cenini, S.; Crotti, C.; Gianella, E. Synthesis of heterocycles via palladium-catalyzed carbonylation of ortho-substituted organic nitro compounds in relatively mild conditions. J. Mol. Catal. 1994, 87, 203-214. [CrossRef]

25. Tollari, S.; Cenini, S.; Ragaini, F.; Cassar, L. Intramolecular Amination of Olefins-Synthesis of 2-Substituted-4-Quinolones from 2-Nitrochalcones Catalyzed by Ruthenium. J. Chem. Soc. Chem. Comm. 1994, 1994, 1741-1742. [CrossRef]

26. Rahman, S.M.A.; Söderberg, B.C.G. A palladium-catalyzed Barluenga cross-coupling-Reductive cyclization sequence to substituted indoles. Tetrahedron 2021, 94, 132331. [CrossRef] [PubMed]

27. Ansari, N.H.; Dacko, C.A.; Akhmedov, N.G.; Söderberg, B.C.G. Double Palladium Catalyzed Reductive Cyclizations. Synthesis of 2,2'-, 2,3'-, and 3,3'-Bi-1H-indoles, Indolo[3,2-b]indoles, and Indolo[2,3-b]indoles. J. Org. Chem. 2016, 81, 9337-9349. [CrossRef] 
28. Hubbard, J.W.; Piegols, A.M.; Soderberg, B.C.G. Palladium-catalyzed N-heteroannulation of N-allyl- or N-benzyl-2nitrobenzenamines: Synthesis of 2-substituted benzimidazoles. Tetrahedron 2007, 63, 7077-7085. [CrossRef]

29. Soderberg, B.C.; Shriver, J.A. Palladium-catalyzed synthesis of indoles by reductive N-heteroannulation of 2-nitrostyrenes. J. Org. Chem. 1997, 62, 5838-5845. [CrossRef]

30. Okuro, K.; Gurnham, J.; Alper, H. Ionic Diamine Rhodium Complex Catalyzed Reductive N-Heterocyclization of 2Nitrovinylarenes. J. Org. Chem. 2011, 76, 4715-4720. [CrossRef]

31. O'Dell, D.K.; Nicholas, K.M. Synthesis of 3-substituted quinolines via transition-metal-catalyzed reductive cyclization of o-nitro Baylis-Hillman acetates. J. Org. Chem. 2003, 68, 6427-6430. [CrossRef]

32. Ragaini, F.; Cenini, S.; Borsani, E.; Dompe, M.; Gallo, E.; Moret, M. Synthesis of N-arylpyrroles, hetero-Diels-Alder adducts, and allylic amines by reaction of unfunctionalized dienes with nitroarenes and carbon monoxide, catalyzed by $\mathrm{Ru}(\mathrm{CO})_{3}(\mathrm{Ar}-\mathrm{BIAN})$. Organometallics 2001, 20, 3390-3398. [CrossRef]

33. Ragaini, F.; Ventriglia, F.; Hagar, M.; Fantauzzi, S.; Cenini, S. Synthesis of Indoles by Intermolecular Cyclization of Unfunctionalized Nitroarenes and Alkynes: One-Step Synthesis of the Skeleton of Fluvastatin. Eur. J. Org. Chem. 2009, 2009, 2185-2189. [CrossRef]

34. Penoni, A.; Nicholas, K.M. A novel and direct synthesis of indoles via catalytic reductive annulation of nitroaromatics with alkynes. Chem. Commun. 2002, 2002, 484-485. [CrossRef] [PubMed]

35. Hsieh, T.H.H.; Dong, V.M. Indole synthesis: Palladium-catalyzed C-H bond amination via reduction of nitroalkenes with carbon monoxide. Tetrahedron 2009, 65, 3062-3068. [CrossRef]

36. Ferretti, F.; El-Atawy, M.A.; Muto, S.; Hagar, M.; Gallo, E.; Ragaini, F. Synthesis of Indoles by Palladium-Catalyzed Reductive Cyclization of $\beta$-Nitrostyrenes with Carbon Monoxide as the Reductant. Eur. J. Org. Chem. 2015, 2015, 5712-5715. [CrossRef]

37. El-Atawy, M.A.; Ferretti, F.; Ragaini, F. Palladium-Catalyzed Intramolecular Cyclization of Nitroalkenes: Synthesis of Thienopyrroles. Eur. J. Org. Chem. 2017, 2017, 1902-1910. [CrossRef]

38. EL-Atawy, M.A.; Ferretti, F.; Ragaini, F. A Synthetic Methodology for Pyrroles from Nitrodienes. Eur. J. Org. Chem. 2018, 2018, 4818-4825. [CrossRef]

39. Su, Z.; Liu, B.; Liao, H.; Lin, H.-W. Synthesis of N-Heterocycles by Reductive Cyclization of Nitroalkenes Using Molybdenum Hexacarbonyl as Carbon Monoxide Surrogate. Eur. J. Org. Chem. 2020, 2020, 4059-4066. [CrossRef]

40. Guan, X.; Zhu, H.; Zhao, Y.; Driver, T.G. Pd-Catalyzed Reductive Cyclization of Nitroarenes with CO2 as the CO Source. Eur. J. Org. Chem. 2020, 2020, 57-60. [CrossRef]

41. Ragaini, F.; Cenini, S.; Brignoli, D.; Gasperini, M.; Gallo, E. Synthesis of oxazines and N-arylpyrroles by reaction of unfunctionalized dienes with nitroarenes and carbon monoxide, catalyzed by palladium-phenanthroline complexes. J. Org. Chem. 2003, 68, 460-466. [CrossRef]

42. Smitrovich, J.H.; Davies, I.W. Catalytic C-H functionalization driven by $\mathrm{CO}$ as a stoichiometric reductant: Application to carbazole synthesis. Org. Lett. 2004, 6, 533-535. [CrossRef]

43. Davies, I.W.; Smitrovich, J.H.; Sidler, R.; Qu, C.; Gresham, V.; Bazaral, C. A highly active catalyst for the reductive cyclization of ortho-nitrostyrenes under mild conditions. Tetrahedron 2005, 61, 6425-6437. [CrossRef]

44. Clawson, R.W.; Dacko, C.A.; Deavers, R.E.; Akhmedov, N.G.; Soderberg, B.C.G. Attempted synthesis of 3-hydroxy-2octadecylindole. Proposed structural revision of previously prepared 3-hydroxy-2-octadecylindole and a proposed structure of fistulosin. Tetrahedron 2009, 65, 8786-8793. [CrossRef]

45. Alessio, E.; Mestroni, G. Catalytic synthesis of aromatic urethanes from nitroaromatic compounds and carbon monoxide, using palladium + 1,10-phenanthroline derivatives as catalyst precursors. J. Mol. Catal. 1984, 26, 337-340. [CrossRef]

46. Bontempi, A.; Alessio, E.; Chanos, G.; Mestroni, G. Reductive carbonylation of nitroaromatic compounds to urethanes catalyzed by (di-1,10-phenanthroline)palladium bis(hexafluorophosphate) and related complexes. J. Mol. Catal. 1987, 42, 67-80. [CrossRef]

47. Wehman, P.; Kaasjager, V.E.; Delange, W.G.J.; Hartl, F.; Kamer, P.C.J.; van Leeuwen, P.W.N.M.; Fraanje, J.; Goubitz, K. Subtle Balance between Various Phenanthroline Ligands and Anions in the Palladium-Catalyzed Reductive Carbonylation of Nitrobenzene. Organometallics 1995, 14, 3751-3761. [CrossRef]

48. Gasperini, M.; Ragaini, F.; Cazzaniga, C.; Cenini, S. Carbonylation of dinitrotoluene to dimethyl toluenedicarbamate; high efficiency of phosphorus acids as promoters for the palladium-phenanthroline catalytic system. Adv. Synth. Catal. 2005, 347, 105-120. [CrossRef]

49. Gasperini, M.; Ragaini, F.; Remondini, C.; Caselli, A.; Cenini, S. The palladium-phenanthroline catalyzed carbonylation of nitroarenes to diarylureas: Effect of chloride and diphenylphosphinic acid. J. Organomet. Chem. 2005, 690, 4517-4529. [CrossRef]

50. Ferretti, F.; Ragaini, F.; Lariccia, R.; Gallo, E.; Cenini, S. New Nonsymmetric Phenanthrolines as Very Effective Ligands in the Palladium-Catalyzed Carbonylation of Nitrobenzene. Organometallics 2010, 29, 1465-1471. [CrossRef]

51. Ferretti, F.; Gallo, E.; Ragaini, F. Nitrogen ligands effects in the palladium-catalyzed carbonylation reaction of nitrobenzene to give N-methyl phenylcarbamate. J. Organomet. Chem. 2014, 771, 59-67. [CrossRef]

52. Ferretti, F.; Gallo, E.; Ragaini, F. Mineral Oil/Methanol: A Cheap Biphasic Reaction Medium with Thermomorphic Properties and Its Application to the Palladium-Catalyzed Carbonylation of Nitrobenzene to Methyl Phenylcarbamate. ChemCatChem 2015, 7, 2241-2247. [CrossRef]

53. Carter, M.E.; Nash, J.L., Jr.; Drueke, J.W., Jr.; Schwietert, J.W.; Butler, G.B. Anionic-Initiated Polymerization of beta-Nitrostyrenes. J. Polym. Sci. Polym. Chem. Ed. 1978, 16, 937-959. [CrossRef] 
54. Berman, R.S.; Kochi, J.K. Kinetics and mechanism of oxygen atom transfer from nitro compounds mediated by nickel( 0$)$ complexes. Inorg. Chem. 1980, 19, 248-254. [CrossRef]

55. Skoog, S.J.; Gladfelter, W.L. Activation of Nitroarenes in the Homogenous Catalytic Carbonylation of Nitroaromatics via an Oxygen-Atom-Transfer Mechanism Induced by Inner Sphere Electron Transfer. J. Am. Chem. Soc. 1997, 119, 11049-11060. [CrossRef]

56. Kunin, A.J.; Noirot, M.D.; Gladfelter, W.L. In situ FTIR spectroscopy at elevated carbon monoxide pressure. Evidence for single electron transfer in the catalytic carbonylation of nitroaromatics. J. Am. Chem. Soc. 1989, 111, 2739-2741. [CrossRef]

57. Belousov, Y.A. Radical chemistry of iron carbonyls. Russ. Chem. Rev. 2007, 76, 41-58. [CrossRef]

58. Belousov, Y.A.; Kolosova, T.A. Electron-spin resonance study of the reaction of iron carbonyls with nitro and nitrosoparaffinesA mechanism of the reductive carbonylation of nitrocompounds. Polyhedron 1987, 6, 1959-1970. [CrossRef]

59. Ragaini, F.; Song, J.S.; Ramage, D.L.; Geoffroy, G.L.; Yap, G.A.P.; Rheingold, A.L. Radical Processes in the Reduction of Nitrobenzene Promoted by Iron Carbonyl Clusters. X-Ray Crystal-Structures of $\left[\mathrm{Fe}_{3}(\mathrm{CO})_{9}\left(\mu_{3}-\mathrm{NPh}\right)\right]^{2-},\left[\mathrm{HFe}{ }_{3}(\mathrm{CO})_{9}\left(\mu_{3}-\mathrm{NPh}\right)\right]^{-}$, and the Radical-Anion $\left[\mathrm{Fe}_{3}(\mathrm{CO})_{11}\right]^{-\bullet}$. Organometallics 1995, 14, 387-400. [CrossRef]

60. Ragaini, F. Mechanistic study of the phase-transfer-catalyzed reduction of nitrobenzene to aniline by iron carbonyl complexes. Role of the radical anion $\left.\left[\mathrm{Fe}_{3}(\mathrm{CO})_{11}\right)\right]^{\bullet-}$. Organometallics 1996, 15, 3572-3578. [CrossRef]

61. Liu, P.H.; Liao, H.Y.; Cheng, C.H. Electro-transfer from tetracarbonylrhodate(1-) to nitro aromatics-novel interaction of nitro radical-anions with a rhodium(I) center. J. Chem. Soc. Chem. Comm. 1995, 23, 2441-2442. [CrossRef]

62. Ragaini, F.; Cenini, S.; Demartin, F. Mechanistic Studies of the Carbonylation of Nitrobenzene Catalyzed by the [Rh(CO)4]-/Bipy System. X-Ray Structure of $[\mathrm{PPN}]\left[\mathrm{Rh}(\mathrm{CO})_{2} \mathrm{ON}\left[\mathrm{C}_{6} \mathrm{H}_{3} \mathrm{Cl}_{2}\right) \mathrm{C}(\mathrm{O}) \mathrm{O}\right]\left[\mathrm{PPN}^{+}=\left(\mathrm{PPh}_{3}\right)_{2} \mathrm{~N}^{+} ; \mathrm{Bipy}=2,2^{\prime}\right.$-Bipyridyl]. J. Chem. Soc. Chem. Comm. 1992, 19, 1467-1468. [CrossRef]

63. Ragaini, F.; Cenini, S.; Demartin, F. Mechanistic Study of the Carbonylation of Nitrobenzene Catalyzed by the $\left[\mathrm{Rh}(\mathrm{CO})_{4}\right]^{-}$ Nitrogen Base System. X-Ray Structure of [PPN][Rh(CO) ${ }_{2} \mathrm{ON}\left(\mathrm{C}_{6} \mathrm{H}_{3} \mathrm{Cl}_{2}\right) \mathrm{C}(\mathrm{O}) \mathrm{O}$ ]. Organometallics 1994, 13, 1178-1189. [CrossRef]

64. Gallo, E.; Ragaini, F.; Cenini, S.; Demartin, F. Investigation of the reactivity of palladium(0) complexes with nitroso compounds: Relevance to the palladium/phenanthroline-catalysed carbonylation reactions of nitroarenes. J. Organomet. Chem. 1999, 586, 190-195. [CrossRef]

65. Tomson, N.C.; Labios, L.A.; Weyhermüller, T.; Figueroa, J.S.; Wieghardt, K. Redox Noninnocence of Nitrosoarene Ligands in Transition Metal Complexes. Inorg. Chem. 2011, 50, 5763-5776. [CrossRef]

66. Popp, B.V.; Thorman, J.L.; Morales, C.M.; Landis, C.R.; Stahl, S.S. Inverse-Electron-Demand Ligand Substitution: Experimental and Computational Insights into Olefin Exchange at Palladium(0). J. Am. Chem. Soc. 2004, 126, 14832-14842. [CrossRef]

67. Todres, Z.V. Cia/Trans Conversion of Potassium Derivatives of 2-Nitrostilbenes and 4-Nitrostilbenes. J. Organomet. Chem. 1992, 441, 349-354. [CrossRef]

68. Álvarez-Calero, J.M.; Jorge, Z.D.; Massanet, G.M. $\mathrm{TiCl}_{4} / \mathrm{Et}_{3} \mathrm{~N}-\mathrm{Mediated}$ Condensation of Acetate and Formate Esters: Direct Access to $\beta$-Alkoxy- and $\beta$-Aryloxyacrylates. Org. Lett. 2016, 18, 6344-6347. [CrossRef] [PubMed]

69. Rimoldi, M.; Ragaini, F.; Gallo, E.; Ferretti, F.; Macchi, P.; Casati, N. Unexpected isomerism in [Pd(2,9-dimethylphenanthroline) $\left.X_{2}\right]$ $(\mathrm{X}=\mathrm{Cl}, \mathrm{Br}, \mathrm{I})$ complexes: A neutral and an ionic form exist. Dalton Trans. 2012, 41, 3648-3658. [CrossRef]

70. Lu, B.-L.; Shi, M. Gold(I)-Catalyzed Tandem Oxidative Ring-Opening/C—C Bond Cleavage Reactions of Vinylidenecyclopropanes with Secondary Amines Under an Oxygen Atmosphere. Chem. Eur. J. 2011, 17, 9070-9075. [CrossRef]

71. Maity, S.; Naveen, T.; Sharma, U.; Maiti, D. Stereoselective Nitration of Olefins with tBuONO and TEMPO: Direct Access to Nitroolefins under Metal-free Conditions. Org. Lett. 2013, 15, 3384-3387. [CrossRef] 